\title{
Evaluation of Allelopathic Effects of Neem, Azadirathta indica A. Juss (Sapindales: Meliaceae) Seed Powder on the Viability of Stored Maize, Zea mays L. Seeds
}

\author{
Philip Wani Marchelo-d'Ragga* and Simon Duku Jebidayo \\ Department of Agricultural Sciences, School of Natural Resources and Environmental Studies (SNRES), University \\ of Juba, P.O. Box 82 Juba, Republic of South Sudan \\ Email: drwani49@gmail.com
}

\begin{abstract}
The present study was carried out at University of Juba Nursery (Latitude $4.50 \mathrm{~N}$, Longitude $31.50 \mathrm{E}$ ) and 457 meters above sea level (msl) to elucidate the allelopathic effects of neem seed powder on viability of stored maize seeds. Maize variety Longe 5 was mixed with neem seed powder as a stored grain protectant at four rates of: $2.5 \mathrm{~g} / \mathrm{kg}(\mathrm{T} 1), 5.0 \mathrm{~g} / \mathrm{kg}(\mathrm{T} 2), 7.5 \mathrm{~g}(\mathrm{~T} 3)$ and $0 \mathrm{~g} / \mathrm{kg}$ (T4-control) neem material / kg of maize seeds.16 maize seeds were taken from each treatment and planted at the rate of four seeds/pot every month for a period of six months. The trial was arranged in a randomized complete block design, and replicated four times. The germination percentage, shoot and root lengths were recorded for each sowing date 10 days after planting (DAP) for the entire period. Data collected were analyzed by the statistical package MSTATC and means separated by LSD test at $\mathrm{P}<0.05$ probability level. Mean germination percentage was $84.4 \%, 85.5 \%, 82.3 \%$ and $86.5 \%$ for T1, T2, T3 and T4 neem preparations, respectively. Shoot and root lengths were not significantly $(\mathrm{P}<0.05)$ affected by the different concentrations of neem seed powder preparations tested. Neem seed powder has no harmful alleopathic effects on maize seed viability and germination for up to the tested period of six months. The abstract should summarize the contents of the paper and should contain at least 70 and at most 150 words. It should be set in 9-point font size and should be inset $1.0 \mathrm{~cm}$ from the right and left margins. There should be two blank (10-point) lines before and after the abstract. This document is in the required format.
\end{abstract}

Keywords: Neem, Azadirachta indica, allelopathy, maize, seed viability, storage.

\section{Introduction}

Maize, (Zea mays L.) is one of five most important cereal crops of the world. It is ranked second after wheat in terms of world grain production [1]. It thrives well in diverse climatic conditions but it is mostly grown by small-holder farmers in developing countries. It occupies less land area than wheat or rice and has the greater average yield per unit area of about 5.5 tons ha-1. Its productivity is thus critical to raising rural income and stimulating broad based economic growth [2]. Maize provides food for both humans and livestock; it is further used in industries in many developed countries. Products such as starches, sweeteners, oil, beverages, industrial alcohol, tooth paste and papers can be obtained from maize. A major problem facing farmers in some developing countries is the rapid losses of maize produce due to postharvest storage pests and diseases. In South Sudan, much money is spent on seed importation every year by governments and nongovernmental organization (NGOs) due to poor yields, losses in storage, owing to poor storage condition of grains for seed. [3, 4] singled out Sitophilus zeamais as major pest that attacks stored maize grains in the tropics and temperate regions of the world. $[5,6]$ indicated that, heavy infestation by this pest in stored maize may result to weight losses of up to 20$90 \%$ in untreated maize. Damaged grains are inferior, have reduced weight and nutritional status. Also, direct market value and seed viability and germination percentage are reduced remarkably. This particular effect on seed viability is a serious production constraint as it affects the successful planting and establishment of maize fields by small scale farmers in new cropping seasons. [7] Estimated the global annual losses in monetary terms due to pests without mentioning specific countries both in the field and storage at more than 100 billion dollars. 
In order to reduce losses in storage, Scientists have rolled out several management techniques and control methods in many parts of the world including the use of synthetic chemical pesticides. However, the tremendous health hazards to humans, livestock and the environment associated with these agrochemicals have forced researchers to seek for safer alternatives that are environmentally friendly [8]. This underscores the reasons behind the steady increase in the use of plant products as cheaper, renewable, locally available, generally non-toxic materials to man and livestock. Furthermore, these plant materials offer an ecologically safer means of controlling insect pest infestations in stored cereals and grains in the tropics where the resource poor farmers are generally found [8]. Such materials include powders and extracts from several plant species namely, drumstick tree Moringa oleifera [9-13]. These materials have been established to be environmentally friendly bio-pesticides and possess many desirable properties. Mixing either dried neem or other plant materials notably desert dates (Balanites aegyptiaca leaf or seed powder with grains in storage has been recommended for use by farmers in some countries [14]. Neem, a well-known tree for its insecticidal properties attributed to the presence of alkaloids as Azadiractin, Selanin and Meliontriol and several other less important minor alkaloids are known to be very effective against a wide range of insect pests including $S$. zeamais [15]. However, these desirable pest control properties of neem have often been associated with toxicity and other adverse allelopathic effects in some crop grains/ seeds treated with either the leaf, seed or bark preparations to some crops namely, cowpeas Vigna unguiculatta Walp., which exhibited significant reductions in seed viability [11, 12, 16-17]. No such investigative studies have been undertaken to evaluate the effects of neem materials/ seed powder on stored maize. Therefore, these studies were objectively incepted to elucidate the possible allelopathic effects neem seed biocide on viability of stored maize under South Sudan conditions.

\section{$2 \quad$ Materials and Methods}

\section{$2.1 \quad$ Location}

The study was conducted at the University of Juba Experimental Nursery Farm (Screen houses) located approximately at Lat. $4.5^{\circ} \mathrm{N}$, and long. $31.5^{\circ} \mathrm{E}$ for six consecutive months.

\subsection{Planting Materials, Collection and Preparation of Neem Seed Powder}

Neem seeds were collected from trees within and around the University of Juba Atlabara Campus, the seeds were washed and cleaned from fruit pulp, sun dried. Afterwards, the dried seeds were grounded into fine powder and kept in an air tight plastic container away from direct sunlight. Maize seeds of variety 'Longe 5' from Magwi County of Imatong State were used in the study. $2 \mathrm{~kg}$ of maize were introduced into storage containers [Muslin bags] measuring $50 \mathrm{~cm} \times 20 \mathrm{~cm}$ to mimic traditional storage sacks and neem seed powder was introduced into the bags at the dose rates of $2.5 \mathrm{~g}, 5.0 \mathrm{~g}, 7.5 \mathrm{~g} / \mathrm{kg}$ and $0 \mathrm{~g} / \mathrm{kg}$ as a control.

Treatment details

T1 $-2.5 \mathrm{gm}$ Neem seed powder $/ 1 \mathrm{~kg}$ of maize seeds

$\mathrm{T} 2-5.0 \mathrm{gm}$ Neem seed powder $/ 1 \mathrm{~kg}$ of maize seeds

T3 $-7.5 \mathrm{gm}$ Neem seed powder $/ 1 \mathrm{~kg}$ of maize seeds

T4 - $0 \mathrm{gm} \mathrm{Neem/} 1 \mathrm{~kg}$ maize seeds or Control (no additives added)

\subsection{Data Collection}

Sixteen maize seeds were retrieved from each treatment each month and planted in pots at the rate of four seeds/per pot. The trial was replicated four times and arranged in a Randomized Complete Block Design (RCBD). The germination percentage was determined from the proportion of germinated seeds to total number of seeds planted expressed as a percentage. The shoot and root lengths of the seedlings were measured 10 days after sowing for each sowing date.

\subsection{Data Analysis}


The data on percentage seed germination shoot length, and root length of seedlings were subjected to analysis of variance (ANOVA) or graphically exploited using Excel work sheet. The means were separated by LSD test at $(\mathrm{P} \leqslant 0.05)$ and results interpreted accordingly.

\section{$3 \quad$ Results and Discussion}

Table 1 shows the germination percentages for all six sowing dates tested which tentatively varied from $70.3 \%$ to $90.6 \%$ indicating good seed viability of the maize seed materials under study which remained intact to the last sowing date. Also, mean germination percentage for the different treatments were $82.3 \%, 84.4 \%, 85.5 \%$ and $86.5 \%$, for T2, T4 (control), T1 and T3, respectively.

Table 1. Mean germination percentage of Maize (Zea mais L.) seeds treated with Neem seed kernel powder.

\begin{tabular}{lccccccc}
\hline Treatments & \multicolumn{7}{c}{ Sowing dates } \\
\cline { 2 - 7 } & $\begin{array}{c}\text { SD-1 } \\
(15 / 2 / 17)\end{array}$ & $\begin{array}{c}\text { SD-2 } \\
(15 / 3 / 17)\end{array}$ & $\begin{array}{c}\text { SD-3 } \\
(15 / 4 / 17)\end{array}$ & $\begin{array}{c}\text { SD-4 } \\
(15 / 5 / 17)\end{array}$ & $\begin{array}{c}\text { SD-5 } \\
(15 / 6 / 17)\end{array}$ & $\begin{array}{c}\text { SD-6 } \\
(15 / 7 / 17)\end{array}$ & Mean \\
\hline $\mathrm{T} 1(2.5 \mathrm{~g} / \mathrm{kg})$ & 68.8 & 93.8 & 100.0 & 75.0 & 81.3 & 93.8 & $\mathbf{8 5 . 5}$ \\
$\mathrm{T} 2(5.0 \mathrm{~g} / \mathrm{kg})$ & 81.3 & 100.0 & 68.8 & 62.5 & 87.5 & 93.8 & $\mathbf{8 2 . 3}$ \\
$\mathrm{T} 3(7.5 \mathrm{~g} / \mathrm{kg})$ & 93.8 & 93.8 & 93.8 & 68.8 & 81.3 & 87.5 & $\mathbf{8 6 . 5}$ \\
$\mathrm{T} 4(0 \mathrm{~g} / \mathrm{kg})$ & 81.3 & 62.5 & 100.0 & 75.0 & 100.0 & 87.5 & $\mathbf{8 4 . 4}$ \\
Mean & $\mathbf{8 1 . 3}$ & $\mathbf{8 7 . 5}$ & $\mathbf{9 0 . 6}$ & $\mathbf{7 0 . 3}$ & $\mathbf{8 7 . 5}$ & $\mathbf{9 0 . 6}$ & $\mathbf{7 7 . 9}$ \\
\hline
\end{tabular}

$\mathrm{SD}=$ sowing dates

Table 2. Effect of Neem seed powder on mean shoot length of maize seeds

\begin{tabular}{lccccccc}
\hline Treatments & \multicolumn{7}{c}{ Date of sowing } \\
\cline { 2 - 8 } & SD-1 & SD-2 & SD-3 & SD-4 & SD-5 & SD-6 & Mean \\
& $(15 / 2 / 17)$ & $(15 / 3 / 17)$ & $(15 / 4 / 17)$ & $(15 / 5 / 17)$ & $(15 / 6 / 17)$ & $(15 / 7 / 17)$ & - \\
\hline T1 & 25.1 & 24.3. & 18.6 & 21.3 & 16.4 & 25.3 & 21.8 \\
T2 & 23.5 & 26.2 & 19.0 & 19.9 & 18.9 & 18.5 & 21.0 \\
T3 & 23.7 & 26.3 & 19.1 & 19.5 & 17.5 & 21.4 & 21.2 \\
T4 & 24.7 & 29.1 & 21.6 & 22.4 & 16.8 & 23.3 & 23.0 \\
Mean & $\mathbf{2 4 . 3}$ & $\mathbf{2 6 . 5}$ & $\mathbf{1 9 . 6}$ & $\mathbf{2 0 . 8}$ & $\mathbf{1 7 . 4}$ & $\mathbf{2 2 . 1}$ & - \\
& & & & & & & \\
CV\% & 11.5 & 14.73 & 14.17 & 14.71 & 22.69 & 20.36 & - \\
SE + Sig. level & 1.37 & 1.95 & 1.38 & 1.53 & 1.97 & 2.25 & - \\
\hline
\end{tabular}

ns $=$ not significant at $\mathrm{P} \leq 0.05$ probability level; $\mathrm{SD}=$ sowing dates

Table 3. Effect of Neem seed powder on mean root length of maize seeds

\begin{tabular}{lccccccc}
\hline Treatments & \multicolumn{7}{c}{ Date of sowing } \\
\cline { 2 - 8 } & SD-1 & SD-2 & SD-3 & SD-4 & SD-5 & SD-6 & Mean \\
& $(15 / 2 / 17)$ & $(15 / 3 / 17)$ & $(15 / 4 / 17)$ & $(15 / 5 / 17)$ & $(15 / 6 / 17)$ & $(15 / 7 / 17)$ & - \\
\hline T1 & 20.1 & 16.3 & 17.7 & 20.4 & 24.9 & 23.3 & 20.5 \\
T2 & 19.0 & 18.0 & 17.4 & 19.1 & 26.7 & 23.6 & 20.6 \\
T3 & 19.4 & 15.7 & 17.3 & 19.9 & 24.5 & 27.1 & 20.7 \\
T4 & 22.1 & 18.1 & 19.1 & 22.9 & 24.3 & 24.9 & 21.9 \\
Mean & $\mathbf{2 0 . 1}$ & $\mathbf{1 7 . 1}$ & $\mathbf{1 7 . 9}$ & $\mathbf{2 0 . 6}$ & $\mathbf{2 5 . 1}$ & $\mathbf{2 4 . 7}$ & - \\
CV\% & & & & & & & \\
SE \pm & 11.54 & 12.58 & 18.99 & 11.61 & 10.35 & 11.50 & - \\
Sig. level & 1.16 & 1.07 & 1.69 & 1.19 & 1.29 & 1.42 & - \\
\hline
\end{tabular}

ns $=$ not significant at $\mathrm{P} \leq 0.05$ probability level $\mathrm{SD}=$ sowing dates 
Again in Table1 the effect of Neem seed powder on mean germination percentage tentatively showed insignificant variations among the four treatments tested. T3 relatively had the highest mean germination percentage, followed by T1, T4, and T2 which showed the least level of germination.

Results from this study indicate no significant differences in the germination of maize seeds treated with neem seed powder preparations compared with the control. [18] Conducted similar studies and established that neem seed powder has a positive influence on protecting maize and cowpea seeds from storage pests without any adverse effects on the viability of the seeds which agree with our findings. [19] Furthermore, broadly indicated that if the allelopathic chemicals are present in sufficiently low concentrations, they may stimulate instead of inhibit the growth of seedlings. However, in our experiments, we did not observe any such findings as tabled by [19] who also did not indicate the dose levels of these allelopathic materials that could stimulate or inhibit the growth of seedlings. We however, did observe some insignificant abnormal germination patterns in which the maize seeds were slightly pushed above the soil levels as is in leguminous plants. Nonetheless, this insignificant phenomenon occurred only occasionally and randomly in some of the treatments, the germination pattern is shown in Figure 1(B).

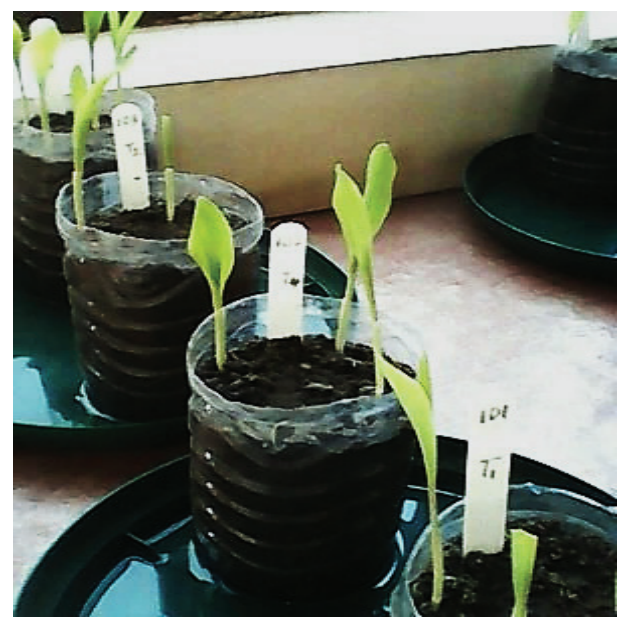

A) General view of normal maize germination

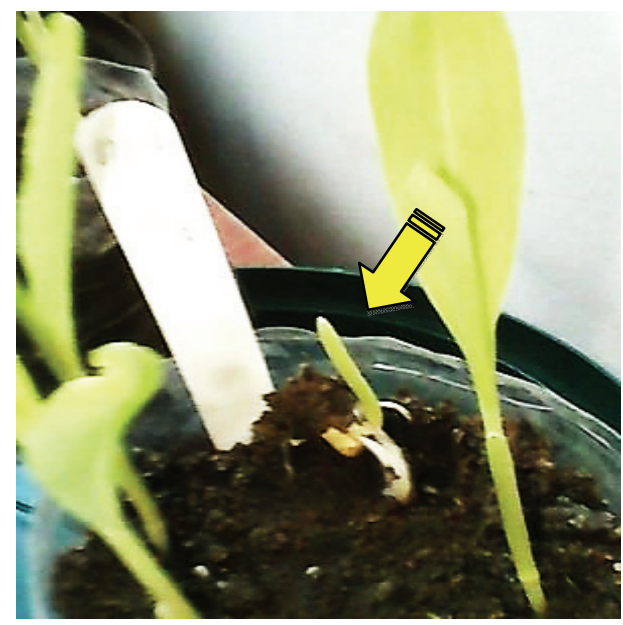

(B) Abnormal germination: note the maize kernel emerging above soil level

Figure 1. The occasional effect of Neem seed powder on the germination of maize seeds note maize kernel emerging above soil level.

Elsewhere, $[9,10]$ working on Arapu leaf powder (Albizia amara) and Moringa oleifera found that Arapu leaf powder maintained good seed viability and seedling vigour for scented rice stored for up to 20 months however, Moringa oleifera had serious allelopathic effects on the viability and germination of Vigna radiata where germination decreased with increasing concentrations of Moringa leaf extracts. [11] Also, working on cowpea found that Neem leaf water extracts inhibited germination as well as suppressed the growth and development of some cowpea varieties with increasing concentrations of neem leaf extracts. These findings agree with the work of $[12,16-17]$. Although in a separate study [20] found that Neem leaf litter and root extracts did not affect the seed germination of Crotalaria ochroleuca but, rather significantly affected the germination of Senna sophera at six days. This therefore, suggests that the different plant biocides in use have differential allelopathic potentials and effects in relation to seed viability, germination and seedling development of other plant and crop species. In this study (Table 1) elucidated the mean germination percentages of: 85.5, 82.3, 86.5 and 84.4 for T1, T2, T3 and T4, respectively and normal seedling development. Furthermore, Tables 2 and 3 showed that the mean root and shoot length of seedlings were not significantly $(\mathrm{P} \leq 0.05)$ affected by neem seed materials for the tested period of six months (24 weeks) for all rates tested. This is in complete agreement with the work of [18] who found no allelopathic effects on maize and cowpeas stored for a period of 12 weeks using neem seed materials at the higher rate of $10 \mathrm{~g} / \mathrm{kg}$ of grain compared to the varied rates and the extended storage period tested in this study. Also, [18] did not observe any atypical germination patterns in maize 
as was reported in this work. However, seed viability and percentage of germination remained high at $95 \%$ and $85 \%$ for maize and cowpeas, respectively.

\section{Conclusion and Recommendations}

The present study has shown that:

○ Neem seed powder biocide has no allelopathic effects on the germination of maize for up to the storage period of six months.

- Farmers can fully utilize neem biocide for seed protection from weevil damage given their wide availability in the country.

- It is recommended that workers should continue the search for more potent and readily available plant biocides for use as seed protectants.

\section{References}

1. O.O. Ogunsina, M.O. Oladimeji and L. Lajide, "Insecticidal action of hexane extracts of three plants against bean weevil, Callosobruchus maculatus (F.) and maize weevil, Sitophillus zeamais Motsch.", Journal of Ecoloy and Natural Environment, vol. 3, pp. 23-28, 2011.

2. D. Byerlee, C. Eicher, and D. Yerlee, Africa's Emerging Maize Revolution. In Africas Emerging Maize Revolution: Lynne Rienner Publishers, 1997.

3. M. Sagheer, A. Khaliq, F.Z.A. Khan, H.T. Gul and K. Ahmad, Assessment of relative resistance in advanced rice genotypes in response to variation in a biotic factors and development of Tribolium castaneum (Herbst) (Coleoptera: Tenebrionidae). International Journal of Biosciences, vol. 3, pp. 33-38, 2013.

4. C.O. Adedire, "Biology, Ecology and Control of Insect Pests of Stored Grains" in Pest of Stored Cereals and Pulses in Nigeria, Ofuya, T.I. and N.E.S. Lale (Eds.). Dave Collins Publications, Nigeria. 2001, pp. 59-94.

5. J. Derera, K.V. Pixley and P.D. Ginga, "Inheritance of maize weevil resistance in maize hybrids among lines in southern Africa, Mexico and CIMMIT-Zimbabwe" in Maize production technology for the future: Challenges and opportunities. Proceeding of the South Eastern and Southern African Regional Maize Conference, 21-25 September 1998. Addis Ababa, Ethiopia: EARO (Ethiopia Agricultural Research Organization) and CIMMYT, Addis Ababa. 1999, pp. 19-23.

6. S. Ganguli, "Neem: A therapeutic for all seasons," Current Science, vol. 82 pp.1304, 2002.

7. A. Yohannes, G. Melaku, M. Derbew, S. Kedir and N. Raja, "Evaluation of certain plant leaf powders and aqueous extracts against maize weevil, Sitophilus zeamais Motsch. (Coleoptera: Curculionidae). Asian Journal of Agricultural Sciences, vol. 6: pp. 83-88, 2014.

8. K.D. Ileke, and M.O. Oni, "Toxicity of some plant powders to maize weevil, Sitophilus zeamais (Motschulsky) [Coleopteran: Curculionidae] on stored wheat grains (Triticum aestivum)", African Journal of Agricultural Research, vol.6, pp. 3043-3048, 2011.

9. M.M Hossain, G. Miah, T. Ahamed and N.S. Sarmin, "Allelopathic effects of Moringa oleifera on the germination of Vigna radiata, International Journal of Agriculture and Science, vol. 4, no. 3, pp. 114-121, 2012.

10. S.D. Raikar, B.S. Vyakarnahal, D.P. Biradar, V.P. Deshpande, and B.S. Janagoudar, "Effect of seed source and seed treatment with chemical and bio-pesticide on storability of scented rice cv. Mugad sugandha", Karnataka J. Agricultural Science, vol. 24, no. 4, pp. 448-454, 2011.

11. S.A. Lawan, M. Suleiman, and S.U. Yuhaya, "Inhibition of germination and growth behaviour of some cowpea varieties using neem (Azadiractha indica) leaf water extract", Bayero Journal of Pure and Applied Sciences, vol. 4, no. 2, pp. 169-172, 2011.

12. W.G. Daniel, "Historical Review and current Models of Forest Succession and Interference" CRC Press, Florida: 251 pp., 1999.

13. J.W. Purseglove, "Tropical Crops: Monocotyledons I". Longman Group Limited, London, 1972.

14. P.W. Marchelo-d'Ragga, and S.K. Binyason, "Evaluation of some plant and other inert materials for the control of Bruchids [Callosobruchus maculatus (Colleoptera: Brucidae)] in stored cowpeas (Vigna unguiculata Walp.). International Journal of Current Agricultural Research, vol. 4, no. 1, pp. 205-207, 2016.

15. NRC, "Neem, A tree for solving Global Problems, National Academy Press, Washington, DC, USA, 1992. 
16. F.A. Einhelling, "Interactions involving allelopathy in cropping systems", Agronomy Journal, vol. 88, pp. 886893, 1996.

17. S. Sazada, Y. Rchi, Y. Kavita, A.W. Feroze, K.M. Mukesh, S. Sudarshana, and J. Farah, "Allelopathic potentialities of different concentration of aqueous leaf extracts of some arable trees on germination and radicle growth of Cicer arietinum Var. - C235". Global Journal of Molecular Sciences, vol. 4, no. 2, pp. 91-95, 2009.

18. C.L. Duruigbo, "Assessing the viability of maize and cowpea seeds stored using local plant Biocides", New York Science Journal, vol. 3, no. 5, pp. 1-3, 2010.

19. R.K. Kohil, H.P. Singh, and D.R. Batish, "Allelopathy and its implication in agroecosystems". Journal of Crop production, vol. 1, pp. 169-202, 1998.

20. S. Ogunyemi, and A.F. Odewole, "Effect of Neem (Azadiratha indica A. (Juss.) on seed germination of Senna sophera L. Roxb. and Crotalaria onchroleuca G. Don". African Journal of Plant Science and Biotechnology, vol. 5, no. 1, pp. 63-65, 2011. 